\title{
KONSEP PEMIKIRAN ISMAIL RAJI AL FARUQI (Dari Tauhid Menuju Integrasi Ilmu Pengetahuan di Lembaga Pendidikan)
}

Aris Try Andreas Putra

Institut Agama Islam Negeri (IAIN) Kendari

Email: aristryandreasputraaritonda@gmail.com

\author{
Jahada \\ Universitas Halu Oleo \\ Email: jahada_uho@gmail.com
}

\begin{abstract}
Abstrak
Wilayah normativitas agama dan ilmu pengetahuan menjadi studi yang selalu menarik untuk dikaji. Pandangan para pemikir ketika memandang agama dan ilmu pengatahuan sangat bervariasi. Sebagian mereka meyakini bahwa wilayah agama terpisah dari ilmu pengetahuan, sebagian yang lain meyakini agama dan ilmu pengatahuan menjadi satu dan tidak dapat terpisahkan. Artikel ini mencoba menjelaskan posisi agama dan ilmu pengetahuan dalam pandangan Ismail Raji Al Faruqi. Al Faruqi berasumsi bahwa ilmu pengetahuan modern memicu adanya perdebatan wahyu dan akal di kalangan umat muslim. Oleh karena itu, Al Faruqi berpendapat bahwa diperlukan sebuah konsep Islamisasi Ilmu pengetahuan yang bertumpuh pada kekuatan tauhid. Pengetahuan Islami selalu menitik beratkan keterpaduan kosmos, keterpaduan kebenaran dan ilmu pengetahuan serta kesatuan kehidupan. Dalam hal islamisasi ilmu pengetahuan Al Faruqi menawarkan landasan objek rencana kerja islamisasi ilmu pengetahuan sebagai berikut: 1) Menguasai disiplin ilmu pengetahuan modern, 2) Menguasai khazanah keislaman, 3) Menentukan relevansi Islam dan hubungannya pada tiap bidang ilmu pengetahuan modern, 4) Mencari metode untuk melakukan sintesis antara spesifikasi keislaman dengan ilmu pengetahuan modern, dan 5) membawa pemikiran Islam pada arah pemenuhan pola sunatullah/ketentuan Allah..
\end{abstract}

\section{Kata kunci: Pemikiran Al Faruqi, Tauhid, Integrasi Ilmu Pengetahuan, Lembaga Pendidikan.}

\begin{abstract}
Religion and science are something that is constantly being studied. The views of thinkers when looking at religion and science must be different. Some believe that the area of religion is separate from science, while others believe religion and science become unified and inseparable. This article will explain the position of religion and science in view Ismail Raji Al Faruqi. Al Faruqi assumed that modern knowledge triggered a revelation and reason debate among Muslims. Therefore, Al Faruqi believes that a concept of Islamization of Science is needed and that the effort is to do something that is tilting on Tauhid. Islamic knowledge always emphasizes the integration of the cosmos,
\end{abstract}


the integration of truth and science and the unity of life. In the case of Islamization of science Al Faruqi offers a grounding object work plan Islamization of science as follows: 1) Mastering of modern disciplines, 2) Master of Islamic literatures, 3) determine the relevance of Islam that are specific to each field of modern science, 4) Looking for ways to make a creative synthesis between Islamic literatures with modern science, and 5) Directing Islamic thought into trajectories that lead to the fulfillment of God's design.

Keywords: Al Faruqi Thought, Tauhid, Integration of Science, Educational Institutions.

\section{Pendahuluan}

Studi Agama dan ilmu pengetahuan merupakan dua wilayah yang terus mendapat tempat yang hangat untuk didialogkan. Agama dan ilmu pengetahuan jika dipandang sebagai suatu studi atau ilmu pengetahuan maka antara keduanya disikapi dengan cara yang berbeda-beda. Akibatnya cara pandang agama dan ilmu pengetahuan juga berbeda dalam meneropong dan mendalami suatu objek. Adakalanya antara agama dan ilmu pengetahuan keduanya berada pada ruang yang saling menyapa, berinteraksi dan berintegrasi, juga disisi lainya mereka berada pada ruang yang bersekat saling membelakangi. Dalam konteks pendidikan Islam, terdapat masalah penting yang harus dijadikan objek kajian yang mendalam. Masalah penting tersebut adalah adanya sekat atau dikotomi antara pendidikan Islam dan ilmu-ilmu umum yang pada akhirnya bermuara pada pembatasan ilmu pengetahuan umum untuk diajarkan pada lembagalembaga pendidikan Islam. Akibatnya lembaga pendidikan Islam kehilangan ruh sains, dan metodologi keilmuan kritis yang sifatnya rasional-empiris. Lembaga pendidikan Islam kini masih ada yang terjebak hanya pada pengetahuan klasik (kalam, fiqih klasik) yang berakar dan membudaya, sehingga pengetahuan itu dianggap telah baku untuk digunakan secara terus menerus. Padahal jika dipahami secara substansi menurut Capra (2000) bahwa, manusia bekerja berdasarkan dua hal, pertama adalah pengetahuan manusia yang bersifat rasional, dan kedua, adalah pengetahuan manusia yang bersifat intuitif. Pengetahuan rasional diasosiasikan dengan sains dan pengetahuian intuitif diasosisasikan dengan agama. Oleh karena itu, sudah seharusnya lembaga pendidikan harus mengakomodir dua cara kerja manusia tersebut.

Nashir (1997, h. 4) menjelaskan, terdapat beberapa hipotesis bahwa telah terjadi kemandekan dalam jalinan komponen perilaku manusia dalam kehidupannya sebagai berikut: pertama terjadi pada level pribadi (individu) yang berkaitan dengan motif, 
persepsi dan respons (tanggapan), termasuk di dalamnya konflik status dan peran. Level kedua, berhubungan dengan norma, yang bertalian dengan hilangnya norma yang menjadi pedoman dalam beraktivitas (normlessnes). Level ketiga, pada level cultural, krisis ini bertalian dengan sifting atau pergeseran nilai pada sosial masyarakat.

Ahmed (1996), menegaskan masalah-masalah kemanusiaan akibat dari filsafat modern memunculkan tanggapan dari berbagai filosof dan ilmuwan, selanjutnya tanggapan dan kritikan terhadap era modern itu melahirkan aliran filsafat Postmodernisme. Posmodernisme memberikan arah ide baru yang moderat pada keragaman. Namun demikian, pemikiran ini walaupun membawa-bawa konsep keragaman namun toleransi terhadap pendukung postmodernisme yang berafiliasi keagamaan kurang mendapatkan posisi. Sehingga posmodernisme juga diklaim sebagai aliran pemikiran yang tidak memiliki korelasi dengan moralitas.

Problem akademik dan problem sosial di atas lantas mendorong banyak pemikir untuk melakukan pembaharuan dan reformasi dalam tataran filsafat dan teologi. Salah satu pemikir muslim yang fokus mencari solusi dari kemandekan peradaban Islam dan pendidikan Islam tersebut adalah Ismail Raji Al Faruqi (pemikir muslim kelahiran palestina). Ancok \& Suroso (2001) menuliskan, Al Faruqi berpendapat bahwa pengetahuan modern memunculkan adanya pertentangan wahyu dan akal di kalangan umat muslim. Oleh karena itu, Al Faruqi berargumen diperlukan Islamisasi ilmu dan usaha tersebut bermula dari konsep tauhid. Hal ini bermakna, pengetahuan Islami selalu menekankan keterpaduan antara kosmos, kesatuan pengetahuan serta keterpaduan hidup. Selanjutnya, Ismail Raji Al Faruqi (1982) menjelaskan, dalam kultur keagamaan umat Islam terbelah menjadi kelompok yang bertahan dan mengusung konservatisme, legalisme dan literalisme. Sementara kelompok lain mencoba untuk melakukan perubahan yang kurang maksimal sehingga terjebak ke dalam alam kebarat-baratan yang mambawa umat Islam jauh dari norma dan ajaran agamanya. Abdullah (1995, h.334) menjelaskan sebagai salah seorang ilmuwan Muslim terkemuka, Al Faruqi berupaya mengimplementasikan ajaran Islam dengan menawarkan konsep ketauhidan dalam bentuk reformulasi pengetahuan baru pada saat memahami konsep tauhid.

Tulisan ini menggambarkan bahwa dalam pandangan Al Faruqi (1992), konsep tauhid yang diinginkannya dalam pembahasan wajah baru atau pengetahuan baru, tergambarkan ketika Al Faruqi melakukan pendekatan dan analisis tauhid yang 
dikorelasikan dengan ragam prinsip dan nilai kemanusian. Konsep tauhid dihubungkan dengan konsep ilmu pengetahuan, prinsip metafisika, prinsip politik, prinsip kehidupan sosial, prinsip ekonomi dan lainnya. Konsep tauhid merupakan dasar bagi seluruh kegiatan atau aktivitas manusia. Ketika konsep tauhid terlepas dari diri individu maka ilmu pengetahuan yang dikembangkan akan menjadi bebas dan sekuler.

Umumnya, masalah besar terjadi ketika ilmu pengetahuan menjadi sangat bebas atau dalam bahasa sederhana ilmu pengetahuan sekuler. Ilmu tidak hanya sekedar untuk ilmu, melaikan ilmu harus diarahkan pada kemaslahatan umat. Ilmu pengetahuan dalam pandangan Al Faruqi adalah harus dapat menggambarkan substansi ajaran Islam. Ilmu pengetahuan harus lahir dan dikembangkan atas dasar prinsip tauhid dengan langkahlangkah yang telah ditulisakan oleh Al Faruqi. Penulis lain juga menyuarakan tentang integrasi ilmu pengetahuan dan agama, namun belum menyentuh wilayah prosedur dan langkah-langkah kerja islamisasi atau integrasi itu. Hanya sebagian kecil saja pemikir Islam yang menyajikan prosedur dan langkah kerja integrasi ilmu pengetahuan dan agama, misalnya di Indonesia dikenal paradigma integrasi-interkoneksi ilmu pengetahuan dan Agama dari UIN Sunan Kalijaga Yogyakarta dengan kerangka “jaring laba-laba”, atau paradigma integrasi dari UIN Maulana Malik Ibrahim Malang dengan kerangka "pohon Ilmu". Penulis dalam artikel ini ingin menampilkan kembali perjuangan integrasi ilmu pengetahuan atau islamisasi ilmu pengetahuan oleh Al Faruqi, sekaligus mengingatkan dan meningkatkan gairah peneliti dan ilmuwan tentang integrasi ilmu pengetahuan dan agama. Oleh karena itu, tulisan ini akan mengurai tentang, bagaimana langkah-langkah kerja islamisasi ilmu pengetahuan serta bagaimana penerapannya pada lembaga-lembaga pendidikan.

\section{Biografi dan Karya-karya Ismail Raji Al Faruqi}

Seperti biografi ilmuan muslim lainnya, Al Faruqi memiliki perjalanan hidup yang cukup menantang dan dinamis. Hijrah secara geografis, sosial dan pendidikan menjadi selimut perjalanan panjang Al Faruqi dalam kehidupannya. Ismail Raji Al Faruqi dilahirkan di palestina di daerah Jaffa, yaitu pada tanggal 1 Januari 1921. Ayahnya bernama Abdul Huda Al Faruqi, seorang qâdhi terkemuka di Palestina. Philip K. Hitti (1974) menguraikan jika dipandang secara geografis, wilayah Palestina awalnya merupakan daerah yang berada di bawah penaklukan Romawi. Selanjutnya palestina dibawa kekuasaan oleh bangsa Arab pada masa khalifah Umar bin Khattab. Pasca masa 
penaklukan atau ekspansi ini penduduknya sebagian besar memeluk Islam dan bersama dengan pasukan Arab turut serta berjihad di dalam berbagai penaklukan dan perluasan wilayah kekuasaan Islam.

M. Shafiq (2000) menuliskan bahwa pada tahun 1948, ketika Palestina diduduki oleh Yahudi, kondisi dan situasi ini memaksa Faruqi dan keluarganya pindah dari Palestina dan selanjutnya bermigrasi ke negeri Paman Sam. Di Amerika Faruqi melanjutkan studi di Indiana University's Graduate School of Arts and Sciences dan memperoleh gelar Master of Art pada bidang filsafat. Pada sekitar tahun 1953, Faruqi dan istrinya pindah dan berdomisili di Syria, kemudian berdomisili ke Mesir pada sekitar tahun1954-1958 dalam usaha menimbah ilmu, untuk mempelajari ilmu-ilmu keislaman pada Universitas al-Azhar Kairo dan proses mempelajari ilmu tersebut, Faruqi berhasil memperoleh gelar doktornya.

Al-Attas (1981, h.139) menjelaskan upaya kolonialisme dan situasi keterbelakangan yang dialami oleh negeri muslim dan khususnya Palestina menjadi penyakit besar yang harus disingkirkan. Situasi inilah yang dirasakan al- Faruqi semasa hidupnya. Konddisi tersebut memicu nalar kritis Al Faruqi untuk mencari solusi dan jalan keluar dari kolonialisme dan kemunduran tersebut. Kolonialisme yang dilakukan oleh bangsa Barat sebagai bangsa yang benci dan sentimen Islam justru diawali dengan kesuksesan mereka mempelajari kemajuan Islam yang membawa bangsa barat ke dalam zaman pencerahan dan selanjutnya melakukan penjajahan terhadap Islam. Pemicu utama dari sikap ini, seperti yang dikemukakan oleh al-Attas.

Lingkungan keluarga Al Faruqi merupakan keluarga yang dikenal sebagai keluaga berpendidikan. Masa kecil Al Faruqi telah mendapat sentuhan proses pendidikan dari sosok ayah yang menjunjung tinggi nilai-nilai keislaman dalam setiap aktivitas kehidupannya. Shafiq (1994) menjelaskan bahwa keluarga Al Faruqi tidak hanya terpandang dan terkemuka dari aspek pendidikan, namun lebih dari itu mereka dari keluarga yang secara ekonomi cukup. Selanjutnya, Harahap (2003, h.97) menjelaskan pendidikan yang ditempuh Al Faruqi, seperti yang dilalui oleh anak keturunan bangsa Arab yang selalu mengutamakan pendidikan agama, Al Faruqi juga memulai pendidikannya dengan pendidikan agama.

Pendudukan Yahudi ke daerah wilayah kelahiran dan dimana Al Faruqi mengabdikan diri membuat situasi tidak kondusif. Dengan jatuhnya Palestina ke tangan 
Israel, al- Faruqi hijrah meninggalkan Palestina menuju Amerika pada tahun 1948. Berpetualangnya Al Faruqi ke negeri Paman Sam bukan hanya dipengaruhi oleh penindasan yang dilakukan kaum Yahudi terhadap masyarakat Palestina. Bannerman, (1989) menuliskan bahwa hijrahnya Al Faruqi lebih disebabkan oleh kekecewaan besar terhadap sistem perjuangan umat Islam yang mementingkan kelompok masing-masing dan tidak bersatu. Kelompok-kelompok tersebut diantaranya Palestine Liberation Organisation (PLO), Harakat al-Muqawwamatul Islamiyyah (HAMAS) dan lainnya.

Lois Lamya (1997) menjelaskan bahwa ketekunannya dalam mempelajari ilmu pengetahuan menjadi lebih baik ketika Al Faruqi mendapat kesempatan melanjutkan pendidikannya di Amerika yaitu pada American University of Beirut dalam konsentrasi keilmuan filsafat. Oleh karena beliau memperoleh gelar dari American University of Beirut, Al Faruqi langsung bertugas sebagai pegawai pada pemerintahan Inggris yang memegang mandat atas Palestina. Al Faruqi berhasil mengabdi dan berkarir sebagai pegawai, selama empat tahun pengabdianya, Al Faruqi dimandatkan menjadi pemimpin wilayah yaitu Gubernur Galilea. Selain beliau melanjutkan pendidikannya di American University of Beirut, beliau juga pernah menimbah ilmu di Indiana University, Harvard dan Al Azhar.

Kehadiran Al Faruqi di Amerika melahirkan inisiatif baru dalam haluan hidupnya berubah dari birokrat untuk menekuni pengembaraan dunia akademis dan sangat fokus terhadap persoalan-persoalan keilmuan. Motivasi yang kuat telah menumbuhkan semangat kepribadiannya untuk menguasai ilmu pengetahuan dengan menempuh studi ke jenjang yang lebih tinggi. Ahmed (1997) menjelaskan, oleh karena dukungan kondisi kehidupan sosial Amerika dan barat pada umumnya yang tidak cenderung diskriminatif dan rasial kepada masyarakat pendatang telah memberi peluang besar bagi Al Faruqi untuk mengimplementasikan potensi keilmuannya. Al Faruqi menimbah ilmu pengetahuan dari beberapa perguruan tinggi terkemuka di Amerika. Bekal ilmu pengetahuannya di Amerika dikombinasikan dengan ilmu keislamannya yang diperoleh di Al Azhar Kairo, menjadikannya sebagai pemikir Islam yang komprehensif. Walaupun demikian hujatan dan tantangan pemikiran juga tidak lepas dari kehidupannya.

Ismail Raji Al Faruqi, Selain sebagai aktivis beliau juga aktif dalam menulis untuk menuangkan gagasan-gagasan sebagai bagian dari kegelisahan akademik beliau. Fokus 
kajian keilmuannya meliputi masalah dunia Islam, modernitas, Ilmu pengetahuan dan Islamisasi Ilmu pengetahuan. Seperti yang tertulis dalam beberapa karyanya di bawah ini:

1. Islam and Modernity: Problem and Prespective, 1968

2. Islam and Modernity: Diatribe or Dialogue? Journal of Ecumenical Studies, 1968

3. The Role of Islam in Global Interreligious Dependences, 1980

4. Izlamization of Knowledge, 1982

5. Christian Ethics: An Historical Atlas of the Religions of the World; Trialogue of Abrahamic Faiths: The Cultural Atlas of Islam.

6. Tawhid: Its Implications for Thought and Live, 1982.

7. Tawhid: Its Implications for Thought and Life. Herndon, 1982.

Berbagai hasil karya dan pemikiran Al Faruqi menjadi referensi bagi studi-studi keislaman para ilmuwan di belahan dunia. Poin penting dari karya dan pemikiran Al Faruqi adalah pentingnya Ilmu Pengatahuan yang berangkat dari nilai-nilai Islam (Al Qur'an dan As Sunah), namun demikian bukan berarti Ilmu pengetahuan Modern ditolak. Melainkan ada proses Islamisasi Ilmu Pengetahuan seperti penjelasan di bawah ini.

\section{Pemikiran Ismail Raji Al Faruqi}

\section{Konsep Tauhid}

Barbour (1966) menjelaskan konsentrasi terhadap kehidupan material dan benda saja tidak dapat memenuhi hakikat hidup manusia, karena manusia memerlukan dimensi spiritualitas dalam system dan pola kehidupannya. Sebagai respons terhadap perkembangan ilmu dan teknologi modern, terdapat kecenderungan para ilmuwan dan para teolog untuk merelasikan dan mendamaikan tujuan yang dipikul ilmu pengetahuan dengan ajaran agama.

Dalam konteks pendidikan, Al Faruqi memberikan konsep pemikiran dan arah baru bertalian dengan paradigma pendidikan Islam selama ini yang selalu mencari dan menerapkan sistem filsafat Barat, terutama tentang konsep dikotomi pendidikan. Menurutnya, dikotomi pendidikan harus dibumi hanguskan dan disubtitusi dengan paradigma pendidikan yang terpadu dan terintegrasi. Konsep pendidikan yang selama ini dibangun dan diterapkan tidak berpedoman pada konsep awal tauhid. Jika Islam memandang tujuan pengembangan obyek didik untuk mencapai awarness atas eksistensi 
tuhan sang pencipta, maka segala aktivitas yang dilakukan untuk menuju tujuan tersebut seharusnya berakar pada konsep tauhid.

Faruqi (1982) menekankan bahwa peradaban Islam adalah Islam itu sendiri dan pokok pangkal ajaran Islam adalah Tauhid atau pengesaan terhadap yang maha cipta, tindakan yang menegaskan Allah sebagai yang Esa, pencipta mutlak dan transenden, penguasa segala yang ada. Namun demikian, tauhid bukan hanya formalitas pengakuan dengan media lisan untuk berikrar akan keesaan Allah serta kenabian Muhammad SAW. Taqi (1996) walaupun ikrar dan syahadat oleh seorang muslim mengkonsekuensikan sejumlah aturan hukum di dunia ini, namun tauhid yang merupakan sumber kebahagiaan abadi manusia dan kesempurnaanya, tidak berhenti pada kata-kata dan lisan. Lebih dari itu tauhid juga harus merupakan suatu realitas batin dan keimanan yang berkembang di dalam hati.

Sebagai landasan awal dalam pendidikan, Al Faruqi membangun konsep pendidikan Islam bermula dari pendidikan keluaga. Menurut Al Faruqi (1982), tauhid sebagai prinsip keluarga, memposisikan keluarga sebagai media untuk memenuhi tujuan Ilahi (penghambaan). Keluarga memancarkan suatu relasi yang luas dan kompleks karena di dalamnya tercipta suatu nilai pendidikan dasar. Nilai pendidikan dasar tersebut seperti nilai mencintai, menolong, mendukung, dan nilai lainnya.

Faruqi (1982), mejelaskan bahwa keluarga merupakan komponen yang terikat dan hidup bersama dalam suasana yang diliputi dengan rasa cinta, percaya dan peduli. Selanjutnya di jelaskan oleh Ramayulis (2001) keluarga menurut Faruqi merupakan media penerjemahan tauhid, artinya aktivitas dalam keluarga harus dilandasi nilai-nilai tauhid (dzikrullah dan persamaan). Bahwa keluarga adalah media untuk mensosialisasikan kandungan tauhid atau tauhid sebagai energi akhlak keluarga, artinya tauhid sebagai pokok daya kerja yang utama bagi manusia untuk berbuat segala aktivitas kebajikan untuk diri sendiri, keluarga, sosial masyarakat, bangsa dan negara. Islam mengajarkan bahwa akhlak tidak didasarkan pada perasaan, tetapi pada tauhid. Urgensi konsep tauhid dalam kehidupan manusia menurut Al Faruqi itu berarti sama dengan pentingnya Islam itu sendiri. Tauhid harus menjadi ruh yang memancar dalam kehidupan setiap muslim. Tauhid menjadi turbin penggerak aktivitas manusia. Segala kegiatan manusia harus bersandar kepada Allah pencipta langit dan bumi. Tauhid harus lahir dalam setiap nafas kehidupan manusia. 


\section{Konsep Islamisasi Ilmu Pengetahuan di Lembaga Pendidikan}

Dalam dunia ilmu pengetahuan kita sering menjumpai istilah clash antara ilmu pengetahuan umum dari barat dan ilmu-ilmu keislaman yang bersumber dari timur, atau timur tengah. Pertentangan itu terjadi pada wilayah ontologi keilmuan. Misalnya ontologi keilmuan barat jarang bahkan tidak pernah menyentuh area ketuhahan, sementara itu ilmu dari timur tengah untuk menggambarkan ilmu keislaman memasukkan area ketuhanan dalam ontologi keilmuannya. Disinilah potensi bahkan realitas clash ilmu pengatahuan itu terjadi. Putra (2015) menjelaskan problem adanya dikotomi antara ilmu-ilmu agama dan ilmu umum menyebabkan tidak berkembangnya ilmu pengetahuan dan terjadinya krisis metodologi keilmuan. Krisis yang terjadi dalam dunia pengetahuan dan pendidikan Islam saat ini mengakibatkan tradisi keilmuan menjadi statis, sehingga pendidikan Islam belum menunjukkan perannya secara maksimal dalam menciptakan peradaban yang maju. Islamisasi ilmu pengetahuan menjadi tawaran konsep bagi kemajuan peradaban lembaga pendidikan. Selanjutnya, Putra (2016) menjelaskan dikotomi sistem pendidikan itu terjadi dalam pandangan filosofis pelaksanaan pendidikan Islam yang berimbas pada praktek dan implementasi pendidikan Islamnya. Sistem pendidikan tradisional/klasik dalam Islam didasarkan pada nilai-nilai ajaran agama yang bersumber dari kalam Tuhan dan hadits Rasul, yang hendak menolak aliran pikir lainya seperti dari kalangan pemikiran religius rasional. Sistem pendidikan tradisional yang tidak bersinggungan dengan ilmuilmu alam dan sains modern, pendidikan seperti ini dikenal dengan pendidikan klasik konservatif.

Islamisasi ilmu pengetahuan adalah konsep yang bertujuan menyaring ilmu-ilmu pengetahuan yang tidak berlandaskan pada nilai-nilai ketauhidan agar sesuai dengan ajaran agama Islam. Menurut Al Faruqi (1982), Islamisasi merupakan upaya "meredefenisi, mereformulasi, mereposisi, argumen dan rasionalisasi yang bertalian dengan berbagai fenomena dan fakta, selanjutnya melakukan penilaian atau reassessment, membuat kesimpulan dan tafsiran baru, menyusun kembali tujuan-tujuan sehingga disiplin ini memperkaya wawasan Islam dan bermanfaat bagi harapan dan citacita umat Islam. Berdasarkan perumusan tersebut maka integrasi ilmu pengetahuan merupakan turbin penggerak dinamisnya kehidupan akademik di lembaga pendidikan khususnya di lembaga pendidikan tinggi. Sejarah mencatatkan setelah Abad 14-15 M peradaban Islam mengalami kemunduran ditandai dengan hancurnya dinasti Abbasiyah 
sebagai bukti besar kejayaan kebudayaan dan peradaban umat islam. Pada saat yang sama lahir semangat bangsa Eropa yang dengan renaisance nya membawa bangsa tersebut meraih puncak kemenangan yang pernah dirasakan dan diperoleh umat Islam pada sekitar abad ke 7 hingga $13 \mathrm{M}$.

Perkembangan ilmu pengetahuan memicu lahirnya beragam konsekuensi dan pengaruh berbagai dimensi kehidupan manusia. Oleh karena itu Islamisasi ilmu pengetahuan dalam pandangan para pemikir Islam merupakan suatu hal yang penting dan harus dilakukan. Khalil (1994) menjelaskan, lahirnya ide islamisasi ilmu pengetahuan berawal dari adanya theological awarness atau kesadaran teologis untuk meningkatkan kualitas ilmu pengetahuan atas pandangan dunia Islam. Menurut Al Faruqi ilmu pengetahuan modern mengakibatkan lahirnya persengketaan atau pertentangan antara wahyu dan akal bagi diri umat Islam, memisahkan pemikiran dari aksi serta adanya dualisme kultural dan religius. Karena diperlukan upaya islamisasi ilmu pengetahuan dan upaya itu harus bermula dari Tauhid. Islamisasi ilmu pengetahuan berarti mengislamkan ilmu pengetahuan moderen dengan cara menyusun dan membangun ulang ilmu pengetahuan sosial, sastra, dan Ilmu alam dengan memberikan dasar argument dan konsep pengetahuan yang berbasis pada ajaran agama Islam. Setiap ilmu pengetahuan harus dituangkan kembali sehingga mewujudkan prinsip-prinsip Islam dalam metodologinya dan kerangka dasarnya.

Faruqi (1986) menjelaskan bahwa seluruh disiplin kelimuan harus diwujudkan kembali sehingga ilmu dapat mengungkapkan relevensi Islam selama ketiga pokok Tauhid yaitu: kesatuan pengetahuan, hidup dan kesatuan sejarah diimplementasikan dalam kehidupan manusia. Sebagai penegasan dari kesatupaduan sumber-sumber kebenaran. Tuhan pencipta alam dari mana manusia memperoleh pengetahuannya. Objek pengetahuan adalah pola-pola alam yang merupakan hasil karya Tuhan.

Faruqi (1989) menguraikan dalam bukunya Islamization of Knowledge bahwa ilmu modern bukannya bersifat universal, tetapi umumnya bersifat etnosentrik dan eurosentrik (kecenderungan ilmu pengetahuan dan tafsiranya hanya berpusat pada benua eropa atau bangsa eropa). Maka ilmu pengetahuan modern tidak boleh digunakan apa adanya, khususnya dalam masyarakat Islam yang mempunyai nilai dan kepercayaan yang berbeda dengan peradaban Barat. Selanjutnya, Hasim (2005) menjelaskan, Al Faruqi melihat pentingnya mengembalikan visi pendidikan Islam pada visi tauhid. Hal ini jelas 
terlihat pada beberapa pemikirannya yang terangkum dalam karyanya "tauhid its implication of knowledge and life". Al Faruqi menjelaskan bahwa seluruh hasil pemikiran ilmu pengetahuan dan aspek dimensi kehidupan harus dijiwai oleh tauhid sebagai esensi utama dalam ajaran Islam.

Islamisasi ilmu Faruqi (1989) yaitu, memuat rencana 12 (dua belas) program kerja untuk islamisasi ini yang kemudian program kerja tersebut dijadikan 5 (lima) landasan objek rencana kerja islamisasi ilmu pengetahuan. Landasan objek tersebut relevan dengan kondisi lembaga pendidikan tinggi sebagai laboratorium implementasi nilai-nilai islamisasi ilmu pengetahuan, sebagai berikut:

1. Menguasai disiplin-disiplin ilmu modern. Disiplin ilmu modern merupakan bidang ilmu sains, dan Ilmu Pengetahuan dan Teknologi.

2. Menguasai ilmu pengetahuan yang memiliki wilayah kajian studi Islam.

3. Menentukan relevansi Islam secara spesifik pada setiap bidang ilmu pengetahuan modern yang ada.

4. Menemukan metode untuk melakukan integrasi, sintesis antara nuansa Islam dengan ilmu pengetahuan modern.

5. Mengarahkan pemikiran Islam pada wilayah atau domain yang mengarah pada terpenuhinya pola rancangan Allah atau sunatullah.

Lembaga pendidikan Islam perlu menerapkan kerangka kerja islamisasi ilmu pengetahuan. Hal ini dilakukan agar lembaga pendidikan Islam tidak kehilangan cirri khasnya yang mengimplementasikan nilai-nilai ajaran Islam. Lima landasan utama kerangka kerja islamisasi ilmu pengetahuan seperti yang dikemukakan oleh Al Faruqi menghendaki keterpaduan atau upaya integrasi antara ilmu keislaman dengan ilmu sains modern. Integrasi dimaksudkan agar ilmu pengetahuan tidak kehilangan substansi ajaran Islam atau substansi ketauhidan. Al Faruqi menekankan bahwa semua disiplin keilmuan dilakukan filter untuk mengkombinasikan antara substansi ajaran Islam dengan ilmu pengetahuan lainnya.

Pemikiran Faruqi (1989) memfokuskan pada sasaran yang bisa dicapai melalui 12 (dua belas) metode sistematis yang pada akhirnya menuju pada Islamisasi ilmu pengetahuan, tepat dilakukan dalam lembaga pendidikan, karena lembaga pendidikan dikelola secara sistematis dan memiliki kerangka kurikulum pelaksanaannya. Langkah tersebut sebagai berikut: 
1. Penguasaan dan pemahaman terhadap ilmu pengetahuan modern. Al Faruqi menekankan bahwa bidang disiplin ilmu-ilmu modern harus diurai menjadi beberapa kategori, prinsip, metodologi, problem, dan tema, yang merefleksikan substansi isi dari ilmu pengetahuan.

2. Peninjauan disiplin keilmuan, jika beberapa kategori dari disiplin ilmu telah dibuat kategorisasi berdasarkan karakteristik masing-masing, maka selanjutnya dibuat kategorisasi dan didisplay dari setiap disiplin ilmu. Langkah ini diperlukan agar ilmuwan muslim dapat menguasai setiap disiplin ilmu pengetahuan modern.

3. Penguasaan ilmu-ilmu keislaman, dibutuhkan pemikiran atau hasil pemikiran berupa karya antologi warisan pemikir muslim yang bertalian dengan disiplin keilmuan.

4. Penguasaan ilmu pengetahuan Islam yaitu melakukan penellaahan atau analisis, jika karya antologi sudah disiapkan, ilmu warisan Islam harus dianalisa dari prespektif fenomena atau problem kekinian.

5. Penentuan relevansi Islam yang spesifik untuk setiap disiplin ilmu. Berkaitan dengan hal tersebut di atas, maka Al Faruqi mengajukan 3 (tiga) masalah pokok sebagai berikut:

a) Apa yang telah disumbangkan oleh Islam, mulai dari al-Qur'an hingga pemikiran-pemikiran pemikir modernis, dalam keseluruhan masalah yang telah dicakup oleh disiplin-disiplin modern.

b) Seberapa besar sumbangan itu memberikan dampak atau pengaruh pada perkembangan peradaban, dan

c) Apabila ada bidang kajian yang sedikit diperhatikan oleh ilmu warisan Islam, kemana arah kaum muslim harus mengusahakan untuk mengisi kekurangan itu, juga bagaimana memformulasikan masalah-masalah itu, dan bagaiamana memperluas visi disiplin tersebut.

6. Penilaian kritis terhadap ilmu pengetahuan modern, apabila ilmu pengetahuan berbasis ajaran Islam telah disusun, maka ilmu tersebut harus dinilai dan dianalisa dari titik pijak Islam.

7. Penilaian krisis terhadap nuansa keislaman, sumbangan ilmu keislaman untuk setiap aktivitas atau kegiatan harus dianalisa dan juga harus membuat relevansiny dengan situasi masa kini. 
8. Identifikasi mengenai problem-problem terbesar umat Islam, melakukan studi sistematis tentang masalah-masalah politik, sosial ekonomi, inteltektual, kultural, moral dan spritual dari kaum muslim.

9. Identifikasi mengenai problem-problem umat manusia, mengidentifikasi masalah pada semua dimensi kehidupan manusia, khususnya pada dimensi pengembangan ilmu pengetahuan.

10. Analisis dan sintesis, pada tahap ini ilmuan muslim harus sudah siap melakukan sintesa antara ilmu-ilmu keislaman dan disiplin modern, serta untuk menjembatani jurang kemandegan berabad-abad. Dari sini khazanah pemikir Islam harus direlasikan dengan ilmu moderen, dan harus mengarahkan ilmu pengetahuan keislaman kepada sesuatu yang lebih luas dari pada yang sudah diperoleh oleh bidang disiplin ilmu pengetahuan modern.

11. Mereformulasi bidang disiplin ilmu pengetahuan dalam kerangka dan metode kerja Islam, Setelah keseimbangan antara ilmu keismana dengan ilmu pengetahuan modern telah dihasilkan, maka semua karya harus dituangkan dalam bentuk integrasi keilmuan. Seperti karya teks pendidikan tinggi (universitas) harus ditulis untuk menuangkan kembali disiplin-disiplin modern dalam bingkai Islam.

12. Menyebarluaskan atau mensosialisasikan ilmu pengetahuan yang sudah diberi nuansa Islam, selain langkah tersebut di atas, media bantu lain untuk mempercepat islamisasi pengetahuan adalah dengan mengadakan berbagai, konsorsium keilmuan, workshop, konferensi-konferensi dan seminar untuk melibat berbagai ahli di bidang-bidang illmu yang sesuai dalam merancang pemecahan masalahmasalah yang menguasai pengkotakan-kotakan antar disiplin. Para pakar yang membuat harus diberi kesempatan bertemu dengan panelis (para tenanga pengajar). Selanjutnya pertemuan pertemuan tersebut harus menjajaki persoalan metode yang diperlukan.

Kaitannya dengan konsep islamisasi ilmu pengetahuan Al Faruqi di lembagalembaga pendidikan, maka lembaga pendidikan Islam kini sadar ataupun tidak telah mengimplementasikan konsep islamisasi ilmu pengetahuan Al Faruqi sebagian atau keseluruhannya. Penulis mencermatinya implementasi islamisasi ilmu pengetahuan dalam dua komponen pendidikan yaitu 1) komponen kurikulum dan 2) pendidik. 
Aspek kurikulum pendidikan; kurikulum dapat dikatakan telah mengkombinasikan ilmu-ilmu pengetahuan modern dan ilmu keislaman. Hal itu terlihat pada uraian visi, misi lembaga pendidikan yang mengarah kepada usaha integrasi, interkoneksi bahkan usaha untuk melakukan transdisiplinaritas keilmuan. Visi misi lembaga pendidikan khususnya lembaga pendidikan Islam kini telah mendesain dan merancang satuan pendidikannya agar menjadi lembaga pendidikan yang integratifinterkonektif. Lembaga pendidikan kini menyajikan konsep interdisipliner, multisipliner bahkan transdisipliner dalam menjawab berbagai pertanyaan akademik dan problem sosial kultural masa kini. Ilmu pengetahuan tidak lagi disarankan berjalan sendiri, namun harus senantiasa bergandengan dengan ilmu pengetahuan lain yang memiliki relasi dan korelasi. Konsep perpaduan ilmu pengetahuan umum dan ilmu keislaman kini telah menjadi fenomena actual di satuan pendidikan. Secara detail konsep kolaborasi disiplin keilmuan tersebut tersaji pada sebaran atau distribusi mata pelajaran dan/atau mata kuliah. Lembaga-lembaga pendidikan seperti madrasah atau perguruan tinggi Islam telah membuat kerangka kurikulum integratif antara ilmu pengetahuan umum dan ilmu pengetahuan agama. Putra (2017) menjelaskan posisi lembaga pendidikan memiliki peran penting di dalam menanamkan nilai, moralitas, agar nantinya individu sebagai makhluk pendidikan memiliki kebijaksanaan dalam menyikapi beragam padangan dan pemahaman tentang sebuah masalah atau fenomena sosial masyarakat. Konsep pemikiran Al Faruqi sebelumnya telah menjadi realitas akademik di lembaga pendidikan. Lembaga-lembaga pendidikan khususnya lembaga pendidikan Islam telah berusaha mendialogkan serta mengintegrasikan substansi ajaran Islam/tauhid dalam berbagai aktivitas keilmuan. Apabila proses integrasi keilmuan menjadi massif dilakukan, maka akan tercipta keharmonisan dalam setiap proses pendidikan. Lembaga pendidikan kini telah mengimplementasikan Ilmu pengetahuan modern dengan ilmu-ilmu keislaman dalam latar proses pendidikan.

Islamisasi ilmu pengetahuan di lembaga pendidikan harus dilakukan dan didukung oleh seluruh sumber daya. Sumber daya yang paling utama adalah sumber daya manusia pendidikan. Sumber daya manusia yang berperan penting dalam proses integrasi ilmu pengetahuan adalah pendidik. Pendidik harus dapat merancang, dan menerapkan pendidikan nondikotomik atau terpadu. Terpadu maksudnya adalah menyatukan ruh ilmu pengetahuan, antara ilmu pengetahuan umum dan ilmu keisalaman. Pendidik harus 
memiliki kerangka keilmuan atau konsep keilmuan yang integratif. Jika pendidik telah memiliki syarat di atas maka pelaksanaan pendidikan, transfer ilmu pengetahuan akan mengarah kepada kombinasi ilmu pengetahuan umum dan ilmu-ilmu keislaman.

Pendidik merupakan penentu keberhasilan dunia pendidikan. Pendidik disebut sebagai tulang punggung bagi terciptanya islamisasi ilmu pengetahuan. Karena pendidik adalah sosok penting yang melakukan perencanaan dan pelaksanaan pendidikan. Pendidik merupakan komponen yang melakukan transfer pengetahuan, transfer nilai dan pembentukan pengalaman baru bagi peserta didik. Pendidik adalah substansi dari kurikulum di lembaga pendidikan. Pendidik jika memiliki kerangka pikir keilmuan yang terpadu, maka transfer pengetahuan kepada peserta didik akan komprehensif, tidak pincang sebelah. Ilmu pengetahuan yang diperoleh peserta didik akan untuh. Peserta didik akan mengenal ilmu pengetahuan umum, ilmu pengetahuan agama dan konvergensi antara ilmu pengetahuan keduanya.

Menurut Faruqi ilmu pengetahuan modern jauh dari substansi ketauhidan. Sehingga perlu upaya islamisasi ilmu pengetahuan dengan memperhatikan langkahlangkah yang telah ditetapkan oleh Faruqi. Langkah tersebut dimulai penguasaan terhadap ilmu pengetahuan modern, mereformulasi kembali ilmu modern, memasukkan substansi ajaran Islam selanjutnya sampai pada kegiatan mensosialisasikan ilmu pengetahuan hasil perkawinan antara ilmu pengetahuan modern dengan khasanah keislaman. Faruqi juga dalam pemikirannya menegaskan bahwa semua hasil pemikiran manusia yang berbuah ilmu pengetahuan, harus diarahkan pada ketetapan dan pola rancangan Allah SWT. Jika diterjemakan dalam situasi pendidikan, maka proses dan output pendidikan harus mengarah kepada substansi ajaran Islam. Berbagai proses dan aktivitas pendidikan selalu disandarkan pada substansi ajaran agama Islam. Substansi kehidupan berilmu pengetahuan itu adalah tauhid.

Disadari bahwa konsep Islamisasi Ilmu pengetahuan Ismail Raji Al Faruqi, juga mendapat berbagai counter opinion atau tantangan ide. Tantangan datang dari berbagai pemikir termasuk dari pemikir Muslim sendiri. Tantangan tersebut tidak menyurutkan keinginan Al Faruqi untuk menggunakan nalar kritisnya dan keilmuannya dalam upaya mereformasi dunia Islam. Al Faruqi justru lebih meningkatkan ide kritisnya. Dia tidak kehilangan gairah dalam berpikir. Gairah berpikirnya terhenti seiring terhentinya denyut jantungnya akibat dia terbunuh. Namun demikian penulis harus menunjukkan apresiasi 
pada pemikiran Al Faruqi, sebab beliau telah berani keluar dari kungkungan modernitas, mengurai masalah pokok dari modernitas yang menurutnya telah jauh dari nilai-nilai ketuhanan. AI-Faruqi meyakini bahwa hanya dengan cara islamisasi ilmu pengetahuan ini visi tauhid yang telah hilang akan diperoleh kembali. Al Faruqi meyakini langkahlangkah yang dilakukannya dapat memberikan pengaruh besar bagi kehidupan peradaban Islam masa kini dan masa akan datang. Generasi yang selalu menyandarkan berbagai kegiatan pada nafas keislaman adalah generasi yang diinginkan oleh Al Faruqi sebagai generasi yang kuat yang dapat berkompetisi dengan siapapun juga dan dalam situasi bagaimanapun juga.

\section{Penutup}

Al Faruqi merupakan pemikir Islam yang berpegangan pada konsep tauhid dalam setiap dimensi kehidupan khususnya yang berkaitan dengan ilmu pengetahuan. Dalam hal islamisasi ilmu pengetahuan Al Faruqi menawarkan kerangka kerja untuk mengintegrasikan ilmu pengetahuan modern dengan ilmu-ilmu keislaman sebagai berikut: 1) Pemikir muslim harus menguasai disiplin-disiplin ilmu pengetahuan modern, 2) selain itu sebagai seorang pemikir harus menguasai khazanah Islam atau menguasai dasar-dasar keislaman, 3) Menentukan hubungan, relevansi dan membuat kategori yang lebih spesifik pada setiap bidang ilmu pengetahuan modern, 4) Mencari cara-cara untuk melakukan analisis dan sintesa antara khazanah Islam dengan ilmu pengetahuan modern, dan 5) Mengarahkan pemikiran Islam kepada domain-domain yang mengarah pada pemenuhan pola rancangan sang pencipta.

Pemikiran Al Faruqi memiliki implikasi positif baik bagi personal pemikir Islam, dan juga pada perkembangan dan integrasi ilmu pengetahuan di lembaga pendidikan. Setidaknya pemikiran Al Faruqi menjadi turbin penggerak semangat pemikir Islam kontemporer untuk melakukan integrasi ilmu pengatahuan, bahkan sampai menciptakan situasi yang lebih tinggi yaitu transdisipliner. Selanjutnya jika diinterpretasikan dan diimplemetasikan dalam praktek pendidikan, maka lembaga pendidikan mempunyai visi yang berbasiskan pada ketauhidan. Wahyu tuhan atau nilai kebaikan harus dijadikan basis, substansi dalam penyusunan tujuan-tujuan pendidikan atau tujuan pendidikan tidak semata-mata hanya berorientasi kebutuhan fungsional dalam latar kehidupan di dunia, namun juga harus mendapat rahmat dan ridha dari Allah SWT sebagai penegasan bahwa 
pendidikan juga berorientasi kepada hari kemudian. Dengan demikian ilmu tidak kehilangan orientasi axiologi, ilmu tidak meninggalkan substansi nilai-nilai islaminya sehingga antara ilmu modern dan khasanah Islam selalu berdampingan dalam ruang dan waktu, berdialog serta saling mendukung antara satu dan lainnya. Pemikiran Al Faruqi memberikan sumbangan pemikiran bagi pemikir Islam generasi baru, agar memperhatikan substansi tauhid dalam setiap aktivitas manusia. Tauhid menjadi pangkal tolak dalam menjalani kehidupan di dunia ini, baik sebagai makhluk individu, masyarakat, maupun sebagai makhluk pendidikan.

\section{DAFTAR PUSTAKA}

Al Faruqi, Ismail Raji dan Lois Lamya Al Faruqi. (1998). Atlas Budaya Islam. terj. Ilyas Hasan, cet.1 Bandung: Mizan.

Al Faruqi, Ismail Raji. (1989). Islamization of Knowledge: general principle and work plan, Virginia: International Institute of Islamic Thought.

Al Faruqi, Ismail Raji. (1982). Islamization of Knowledge: General Principles and Workplan Herdon Virginia: IIIT.

Al Faruqi, Ismail Raji. (1986). Islamization of knowledge: the General Principles and the Workplan dalam Knowledge for what? Islamabad-Fakistan: National Hijra Council.

Al Faruqi, Ismail Raji. (1982). Tawhid: its Implications for Thought and Life, Kuala Lumpur: the International Institute ofIslamic Thought.

Butt, Nasim. (1996). Sains dan Masyarakat Islam. Badung: Pustaka Hidayah.

Capra, Fritjof. (2000). The Tao of Psycis: Menyingkap Kesejajaran Fisika Moderen dan Mistisme Timur, Bandung: Mizan.

Djamaluddin Ancok \& Fuat Nashori Suroso. (2001). Psikologi Islami: Solusi Islam atas Problem-problem Psikologi. Yogyakarta: Pustaka Pelajar.

Haedar Nashir. (1997). Agama dan Krisis Kemanusiaan Modern. Yogyakarta: Pustaka Pelajar.

Ian.G. Barbour. (1966). Issues in Science and Relegion. New York: Herper Torchbooks.

Khalil, Imanuddin. (1994). Pengantar Islamisasi Ilmu Pengetahuan dan Sejarah. Jakarta: Media Dakwah.

Lois Lamya Al Faruqi. (1997). Allah Masa Depan Kaum Wanita, terj. Masyhur Abadi Surabaya: Penerbit al-Fikri.

M. Shafiq. (2000). Mendidik Generasi Baru Muslim. terj. Suhadi, cet. 1, Yogyakarta: Pustaka Pelajar.

Muhammad Naquib al-Attas. (1981). Islam dan Sekularisme. terj. Karsidjo, Bandung: Penerbit Pustaka. 
Muhammad Shafiq. (1994) The Growth of Islamic Thought in North America focus on Ismail Raji Al Faruqi, USA amana publication.

Muhammad Taqi. (1996). Monoteisme Tauhid sebagai sistem Nilai dan Akidah Islam. Terj. oleh M.Hashem dari At Tauhid or Monotheisme: asin the ideological and the value Systems of Islam. Jakarta: Lenterabastitama.

Patrick Bannerman. (1989). Islam in Perspective; a Guide to Islamic Society, Politic and Law. London: Rutledge.

Philip K. Hitti. (1974). History of the Arabs. London: Macmillan Press LTD.

Putra, Aris Try Andreas. (2015). Pemikiran Filosofis Pendidikan Ibnu Sina dan Implikasinya pada Pendidikan Islam Kontemporer, Jurnal Literasi Ilmu Pendidikan, 6(2).

Putra, Aris Try Andreas. (2016). Determinasi Worldview Keilmuan dan Damainya SainsAgama, Zawiyah: Jurnal Pemikiran Islam, 2(1).

Putra, Aris Try Andreas. (2017). Prespektif Insider dan Outsider dalam Studi Keagamaan (Telaah Pemikiran Kim Knott tentang Pendekatan dalam Meretas Problematika Kehidupan Beragama di Indonesia), Zawiyah: Jurnal Pemikiran Islam, 3(2).

Ramayulis. (2001). Pendidikan Islam dalam Rumah Tangga. cet. 4, Jakarta: Kalam Mulia.

Rosnani, Hasim. (2005). Gagasan Islamisasi Ilmu Pengetahuan Kontemporer. Islamia, 2(6).

S. Ahmed, Akbar. (1996). Postmodernisme: Bahaya dan Harapan bagi Islam. Terj. Panegstuningsih, Bandung: Mizan.

S. Ahmed, Akbar. (1997). Membedah Islam. terj. Zulfahmi Andri, Bandung: Pustaka Salman.

Syahrin Harahap. (2003). Ensiklopedi Aqidah Islam. Jakarta: Kencana.

Taufik Abdullah. (1995). Ensiklopedi Islam. Jilid I, Jakarta: Ikhtiar Baru Van Hoeve. 